\title{
An Assessment of Housing Condition and Socio-Economic Life Styles of Slum Dwellers in Akure, Nigeria
}

\author{
Kayode Felix Omole \\ Federal University of Technology \\ E-Mail: fkyomole@yahoo.co.uk
}

\begin{abstract}
This paper examines the importance of housing to man as an essential need and a prerequisite for the survival of man after food. It equally recognizes profound influence it has on the health, behaviour and efficiency of man and the nation as a whole. The study was carried out with the aid of questionnaire administration, building and facility survey Using random sampling technique, every 5th houses in the five district areas was picked for interviewed. Also, data were collected from related government ministries and departments to particular find out government's intervention in this area. Findings from the study reveal that the area chosen for the study exhibit slum condition that has undenied impact on the socio-economic lifestyles and the health of the residents, as well as the general outlook of the environment. Recommendations were proffered to guide the policy makers towards enhancing the lives of the residents of the area. Some of which include upgrading programme through the provision of urban basic services and improved sanitation strategies for sustainable management of the area, Public enlightment campaign is also recommended so that the residents will know the importance of good living condition to their health and as well to know the danger of abusing their environment.
\end{abstract}

Keywords: Housing, Life-Style, Slum, Income, Health

\section{INTRODUCTION}

Housing is often regarded as one of the basic human needs. It ranks second after food and thereafter clothing. It is a pre-requisite for the survival of man (Onibokun, 1985). Housing as a unit of the environment has profound influence on the health, efficiency, social behaviour, satisfaction and general welfare of the community. It reflects the cultural, social and economic values of a society, as it is the best physical 
and historical evidence of the civilization of a country. Adedeji (2004) argued that housing issues affect the life of individuals as well as that of a nation; hence both nature and society ascribed great importance to the role it plays to bring about human comfort. The importance of providing adequate and quality housing in any country cannot be overstated nor disputed in time or space. It is a stimulant to the national economy. However, the re-current nature of housing needs and the unending desire for good housing tend to confirm the widely impression that there is hardly any society that has been able to cope satisfactorily with its housing requirement (Modupe, 1986).

The proliferation of shanty dwellings, squatter settlements and slums in most of our cities in the Nigeria and other less developed nations of the world is attributed to a chain of factors. Of course, such factors are closely associated with the low level of socio-economic and cultural lifestyles of the inhabitants. This paper, therefore, intends to investigate the characteristics of housing condition vis-à-vis the socio-economic lifestyle of slum dwellers in Akure (Nigeria) with a view to determining the factors that are actually responsible for the formation of slum conditions in urban settings.

\section{LITERATURE PERSPECTIVE}

The World Health Organisation (WHO) describes housing as residential environment which includes the physical structure used for shelter, all necessary services, facilities, equipments and devices needed or desired for the physical and mental health and social well being of the family and individuals. The United Nations Ad-Hoc Group of Experts on Housing and Urban Development equally asserted that housing is neither a mere shelter nor household facilities alone. It is an essential need that comprises essential services and facilities, which make up a physical environment that link such individuals and his family to the community in which it evolves. Therefore, environmental amenities like waste disposal, water supply, road access and location services implied by the special links between necessary economic and social infrastructure like education, health and recreation are all parts of the package of services designated as housing (Aribigbola, 2001).

Slum is believed to be an element of urban decay, which Onoekerhoraye (1995) and Omole (2001) described as permanent dwelling areas, which have become derelict through age and neglect. It is clearly defined by George (1999) as a group of buildings or an area characterized by overcrowding, deterioration, unsanitary conditions, or absence of basic and essential facilities like portable water, drainage system, schools, health facilities, recreational grounds, post office, among others. Basorun (2003) 
quoting Abiodun (1995) sees slum as a bulk of traditional housing in dilapidated condition, which are unsuitable for habitation.

The impacts of slum condition on socio-economic lifestyles and health conditions of its residents are real and obvious. In a study by George (1999) for example, argued that the neglect of buildings occasioned by low capital base of the inhabitants bring about the emergence of slum while the physical deterioration of the area encourages springing up of slum development. Poverty, illiteracy, crowdness, health problem, crime and social vices are important features of slum areas. Earlier studies focused much on the physical appearance of dwelling units with the aim to assess the dimensions of the slum problem externally. But recent studies have considered socioeconomic aspect of slum as well as the health of the inhabitants very crucial. For instance, Bello (2002) emphasized that slum areas are locus of poverty where various factors that enhance slum development and growth are noticeable. He admitted that congestion of building and people as potent factors that created opportunities for the emergence of low environmental quality and unsanitary conditions, which breeds contagious diseases and infections in such deplorable parts of urban area.

In a related study carried out by Olanrewaju and Akinbamijo (2002), it was affirmed that environment has great and obvious effects on health as poor residents are often seen at zones, which imply poor health. They observed slum dwellers to be group of people who live in old houses with bad structures located in poor environments where they are exposed to ill health from polluted water. Such houses are without toilet and other essential utilities. Their drains are often filled with refuse deposits, which hamper the free flow of run-offs. Similarly, Onibokun and Kumuyi (1996) identified slum areas as regular abodes for urban poor. Such are characterized by low income, unstable employment, low status of job, poor housing conditions, large facilities, and constant struggle for survival. Also they are distinguished by low access to limited information (Olanrewaju, 2004)

The problem of low income affects the level of capital formation, which deprives the people of sufficient resources to utilize in improving their homes and keep their environment healthy for comfortable living. This is responsible for the reason why six to ten people would live in a room (George, 1999).

The problem of slum formation is not restricted to urban centers, it extents to the peripheries and the rural areas. According to Wahab (2001), rural settlements are often faced with qualitative housing problems, lack of basic amenities and facilities, low standard of living, abject poverty, and rural-urban migration. He asserted that the problems facing slum and squatter settlements in Nigeria presently have effects on 
social equity, human health and well being, economic welfare, socio-political stability, housing infrastructure, community facilities and services as well as sustainability of natural resources.

The United Nations Habitat Report (1989) affirmed that a large proportion of the third world's urban population lives and works in very poor condition. Apart from the fact that the poor inhabit many different low quality forms of housing, there are two other basic environmental problems that are evidently noticeable. One is the presence of pathogens in the human environment due to lack of basic infrastructure and services. The second is crowded and cramped living conditions. The report shows that lack of infrastructures, readily available drinking water, sewerage facilities to dispose human wastes hygienically, garbage and refuse disposal facilities as well as lack of basic measure to prevent and provide primary health cares ensure that many debilitating and endemic among the urban poor holds. Such diseases include diarrhea, dysentery, typhoid, intestinal parasites and food poisoning.

Many cities in Africa and Asia are seriously affected with this condition. Most of these cities do not have sewer; hence, their human excreta and wastewater ends up in rivers, streams, canals, gullies and ditches untreated. To improve the life of the poor in such deplorable parts of urban centre through physical planning, Olanrewaju (2004) suggested, with particular reference to Akure that urban renewal in form of rehabilitation and upgrading programme will be suitable. This is in a view to providing the essential facilities and revive the outdated ones rather than embarking on total clearance and redevelopment that can affect the residents negatively.

\section{AIMS AND SCOPE OF STUDY}

The study seeks to assess the condition of housing and the socio-economic life style of slum dwellers in Akure urban centre. To effectively carry out this assessment, the various components of the buildings need to be examined in terms of materials used for construction, age of building, structural condition of building, level of household facilities and infrastructure available within the neigbourhood. Also, the literacy level, occupation and income distribution pattern of respondents, the effects of slum condition on the residents were equally investigated.

\section{THE STUDY AREAS}

Various expressions have described slum areas as congested district, characterized by deteriorating, unsanitary housing environments and noticeably poverty area. Hence, the areas chosen for this study include: Araromi, Oja Oshodi, 
Odo Ikoyi, Isolo and Ijomu via Oke-Ijebu in Akure exhibit evidence of slum environment. The area is located in the northeastern part of the town towards the right while coming from Alagbaka Estate. It is directly opposite the Town Hall and the General Post Office Complex, an adjacent landmass to the town's Central Business District. The main river that drains the area is River Ala. Figure 1 shows the study areas in the local governments setting while figure 2 shows the location of the study areas.

\section{RESEARCH METHODOLOGY}

The data for this study was collected through primary and secondary sources. Questionnaire administration constitutes the major instrument used in information collection. Map upgrading, building and facility surveys supplemented this. Information from related ministries and government departments, particularly the state Ministry of Environment, Town Planning Office and Akure South Local Government Secretariat were also used.

Altogether, there are 1,306 existing buildings in the area of about 3.6 square kilometers. Out of these, 48 are non-residential leaving 1258 as target population. From this, a 20\% sample size, amounting to 250 buildings was taken and considered reasonable for the study. Using systematic random sampling approach to select respondents in the area, every $5^{\text {th }}$ house in each of the five districts involved was taken for the interview. Meanwhile, only one household was interviewed in each of the buildings selected. Each questionnaire contains 45 variables, which were thoroughly investigated to obtain information on sex, marital status and age of respondents. Also, the residences' socio-economic characteristics, structural condition of buildings, the level of infrastructure facilities as well as residents' perception of their environment were investigated.

\section{FINDINGS AND DISCUSSION}

The research findings in this study are presented primarily on the existing situation in the area, considering the socio-economic characteristics of respondents, the structural condition of buildings, the state of the existing infrastructure facilities, the general condition of the environment, and the effects of slum on the residents. Meanwhile, twenty (20) of the two hundred and fifty (250) questionnaires distributed could not be retrieved leaving two hundred and thirty (230) which were used for the analysis. This represents $92 \%$ of the total expected responses. It is still considered reasonable when taking into consideration the homogeneous characteristics of slum areas. 


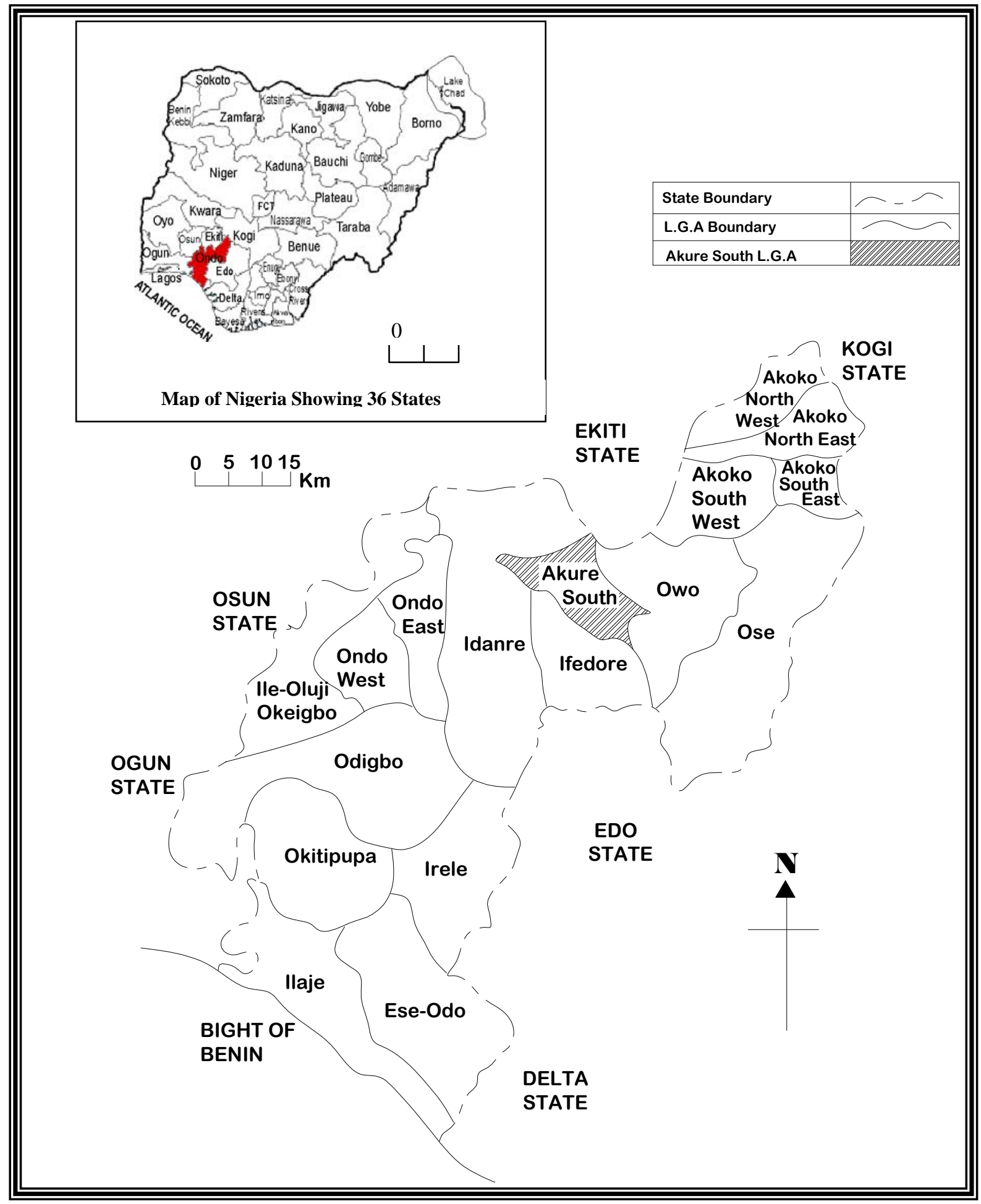

Figure 1 Ondo State Showing Akure South Local Government Area 


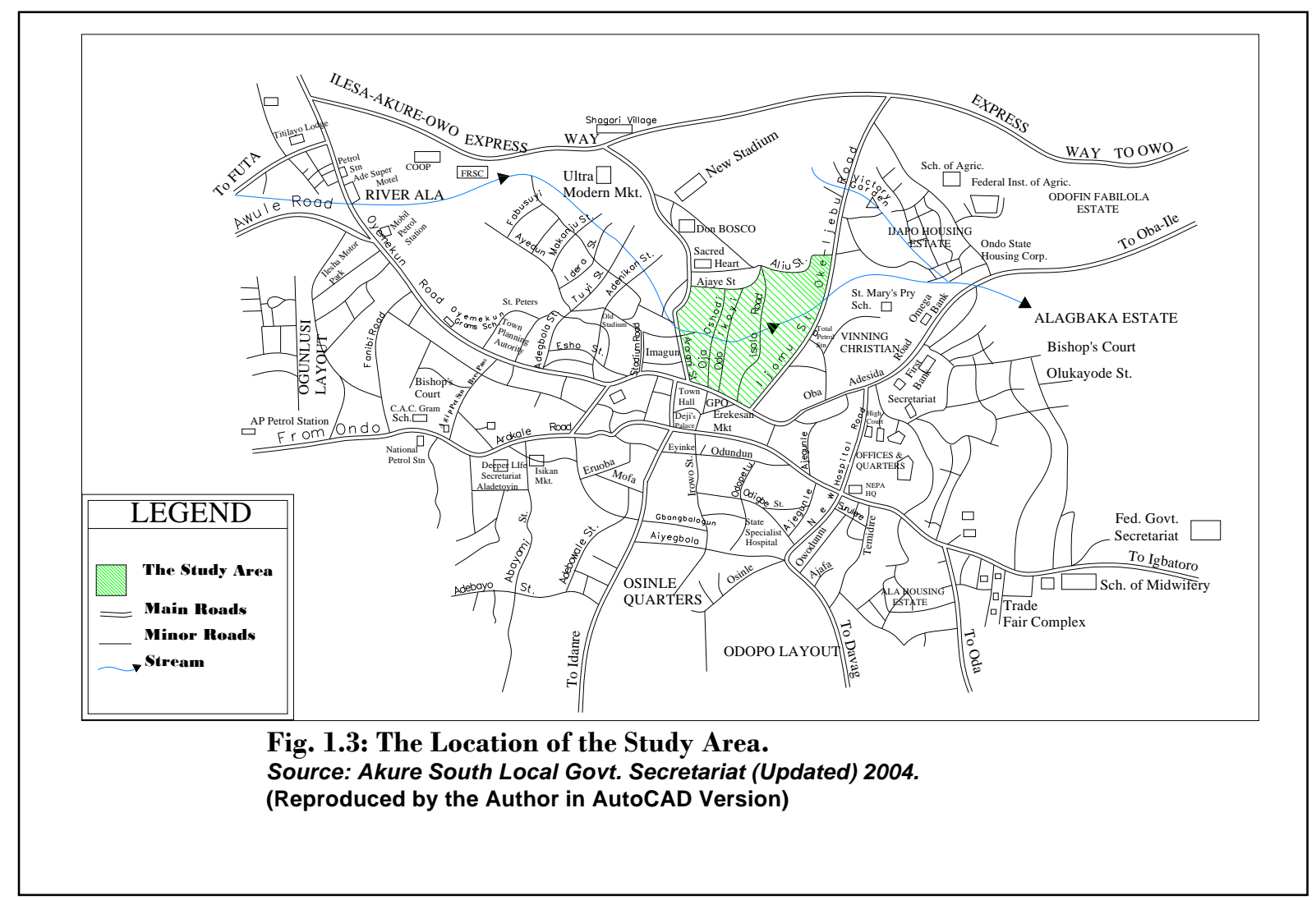

Figure 2 Akure Street Map Showing the Location of the Study Area

\section{Socio-economic Lifestyle of Respondents}

The questionnaire administration was concentrated mainly on adults within age bracket of 25 years and above. This constitutes about $92.6 \%$ of the sampled respondents. There was fair distribution between the two genders of $51.3 \%$ male to $48.7 \%$ female. Out of these $70.4 \%$ are married, $15.2 \%$ are single, and $13.9 \%$ are widow while $0.4 \%$ is separated. Information gathered on educational background reveal that more than half of the inhabitants in the area are illiterates who do not enjoy the benefits of formal education. This constitutes about $56.1 \%$ of the respondents. As shown on Table 1, out of 101 who claimed to be literate, $23.5 \%$ have only primary school leaving certificate, while $12.6 \%$ attempted secondary school and only $7.8 \%$ have tertiary education. The implication of the low level of education of the people in the area undermined the importance of healthy environment therefore live below the minimum environmental standards stipulated in the planning code of the country.

The occupational and income distributions are closely related. The nature of occupation determines their level of income. About 31\% engage in trading activities, $19.1 \%$ in different craftworks like weaving, tailoring, vulcanizing, mechanics, etc 
while $13.5 \%$ engage in farming. Only $8.3 \%$ are civil servants while the remaining are either unemployed (23.9\%) or apprentists (4.3\%). Thus, about $51.3 \%$ receives monthly income below $\$ 5000$ out of which $19.1 \%$ have no stable source of income. About $40.4 \%$ receives between $\$ 5000$ and $\$ 15000$ while only $8.3 \%$ receives above $\$ 15$, 000. The finding here revealed that the general income is below the national average of $\$ 7000$ per month and also found to be below the state average income level of $\$ 6500$ per month. With this low income distribution, to afford good quality housing, proper maintenance of existing ones and adequate feeding might be very difficult, if not impossible. Besides this, the household size distribution is high. Majority of the households were made up of between 5 to 6 people. This accounts for about 36\% followed by 3 to 4 household size (27\%) while 5.2\% has 9 to 10 . (See table 1).

\section{Assessment of Housing Quality}

The quality of housing in the study area is very low due to the low quality materials used for construction and the inadequate technology as well as poor planning standards of handling the building components. Over $80 \%$ of the buildings have spent 30 years. Only $10.5 \%$ of the total housing stocks in the areas are buildings of recent construction, which are below 20 years. The work of Fadamiro (2001) become relevant here in which he argued that there is a correlation between relative habitability of the housing and their ages. According to him, buildings erected in more recent times tend to be more habitable than buildings built much earlier. Hence, a large number of the housing stocks in the areas of study have relatively low habitability, which has direct effects on the state of health, socio-economic well being and emotional stability of the residents.

Roofing materials of the buildings in the area are $97.8 \%$ of zinc coated corrugated iron sheets types, only about $2.2 \%$ are made of asbestos materials. This shows that the level of technology of building construction in the area is yet to catch up with modern age. It still remains crude and traditional, so is the level of maintenance. Over $80 \%$ of the buildings need either minor or major repairs, out of which $18.3 \%$ are completely old and dilapidated. Only 15.2\% exhibit evidence of physical soundness (See tables 2). 
Table 1 Socio-Economic Characteristics of Respondents

\begin{tabular}{lc}
\hline Character & Percentage \\
\hline * Sex Distribution & \\
\hline Male & 51.3 \\
Female & 48.7 \\
\hline * Age Distribution & \\
\hline Below 25 & 7.4 \\
25-29 years & 22.6 \\
30-39 years & 26.1 \\
40-49 years & 15.7 \\
50 years and above & 28.7 \\
\hline * Marital Status & \\
\hline Single & 15.2 \\
Married & 70.4 \\
Widow & 13.9 \\
Separated & 0.4 \\
\hline * Educational Level & \\
\hline No Formal Education & 56.1 \\
Primary & 23.5 \\
Secondary & 12.6 \\
Tertiary & 7.8 \\
\hline * Occupational Pattern & \\
\hline Farming & 13.5 \\
Craftsmanship & 19.1 \\
Trading & 30.9 \\
Civil Service & 8.3 \\
Unemployed & 23.9 \\
Apprentices & 4.3 \\
\hline * Income Level & \\
\hline No fixed Income & 19.1 \\
Below N5,000 & 32.2 \\
N5,000- 10,000 & 21.7 \\
N10, 000- 15,000 & 18.7 \\
Above N15,000 & 8.3 \\
\hline 1-2 Persons & \\
3-4 persons & 17.8 \\
5-6 persons & 27.0 \\
7-8 persons & 36.1 \\
9-10 persons & 13.9 \\
\hline$\quad$ Soure: Fize & 5.2 \\
\hline
\end{tabular}

Source: Field Survey, 2006 


\section{Assessment of Infrastructure Facilities}

The infrastructure identified in the areas includes both sanitary and general facilities. According to the grouping made by the Federal Ministry of Housing and Environment, Lagos (1982), sanitary facilities include toilets, bathrooms, kitchen, water supply and refuse disposal while the general facilities include electricity supply, road accessibility, security, health and educational facilities as well as spaces for washing and drying of clothes.

1. Sanitary Services: Findings made from the study reveal that pit latrine is rampant in the area, which accounts for about $65.2 \%$. Only $10.9 \%$ used modern day water closet while a whole $23.9 \%$ do not have provision for this facility at all. Such buildings only make use of mobile latrine (4.8\%), bush and dunghill (11.3\%), stream and drainage channels (7.8\%) or squatting in the neighbouring houses. Without any doubt, this condition has innumerable attendant problems, it contributes to the deplorable condition of the area. It makes the area look ugly, stinking and unattractive. Even some with modern toilets lack good septic tanks while a large number of them could not get water in their toilet.

Besides, the condition of bathroom, kitchen and water facilities is very ridiculous in the area. From Table 3, a large proportion of the buildings examined have these facilities, only that they are substandard, inadequate or inconveniently located. Many of the bathrooms are just small enclosures, some of which are made of non-durable materials like bamboo, rusted iron sheets, or planks at the backyard. The use of firewood and charcoal for cooking is prevalent, hence many of the buildings have their kitchens located at the backyard, except for the few ones that used kerosene stoves as supplement to cook at the passage or right inside their rooms.

The main source of water supply is largely through underground well water, some of which have shallow depth. This poses some problems because the water is not treated before use. Only few, about $14.3 \%$ enjoy tap water, which is not regular. From this situation, the existing water supply does not guarantee quality water supply in the area, hence the people are at greater risk of contacting acute water borne diseases. The state of waste disposal in the area is generally absurd in spite of government efforts to curb indiscriminate disposal. Over 30\% dispose their refuse indiscriminately, some in open spaces (21.3\%), some through burning within residential environment thereby causing air pollution (11.7\%) while $1.7 \%$ disposes theirs at road sides and drainages where nobody cares for them. This hampers the free flow of run-off and constitutes comfortable breeding grounds for flies, mosquitoes and 
other health-infected animals that could contribute to the spreading of diseases. (See table 3).

Table 2 Building characteristics

\begin{tabular}{lc}
\hline Materials used for construction & Percentage \\
\hline Walling- Mud or mud blocks & 79.1 \\
- Cement blocks & 20.9 \\
Roofing- Zinc/ corrugated Iron sheet & 97.8 \\
- Asbestos materials & 2.2 \\
\hline Condition of Building & \\
\hline Walling- Plastered/ Half plastered & 51.3 \\
- Plastered and painted & 32.6 \\
- Not plastered & 13.9 \\
- Cracked & 2.2 \\
Roofing- Good & 37.4 \\
- Leaking & 29.1 \\
- Patched & 33.4 \\
- Need minor repairs & 15.2 \\
- Need major repairs & 34.8 \\
- Dilapidated and old & 31.7 \\
Structure- physically sound & 18.3 \\
\hline Age of Building & \\
\hline Below 10 years & 4.8 \\
10-19 years & 5.7 \\
\hline Solow 40 years & 7.8 \\
\hline years & 23.9 \\
\hline years and above & 57.8 \\
\hline Field survey, 2006 & \\
\hline
\end{tabular}

2. General Facilities: The main source of electricity supply to the area is through the Power Holding Company of Nigeria (PHCN), which accounts for over $90 \%$ of the sampled buildings. About $1.7 \%$ used generating plant as supplements while $17.4 \%$ depends solely on hurricane lamps. This is quite impressive except for the erratic nature of light supplied by the PHCN. There are cases of the area been put in total darkness for weeks or sometimes months! 
Table 3 Distribution of Sanitary Services

\begin{tabular}{lc}
\hline Facilities & Percentage \\
\hline - Sewage Disposal (Toilet) & \\
\hline Pit latrine & 65.2 \\
Water closet & 10.9 \\
Bucket latrine & 4.8 \\
None- Bush and dunghills & 11.3 \\
$\quad$ - Streams and drainages & 7.8 \\
\hline - Bathroom Facilities & \\
\hline Indoor- Self contained & 4.2 \\
$\quad$ - Shared & 53.9 \\
Out door- open courtyard & 31.7 \\
Not available & 10.0 \\
\hline - Kitchen Facilities & \\
\hline Indoor- self contained & 5.2 \\
$\quad$ - Shared & 63.0 \\
Outdoor- open courtyard & 28.3 \\
Not available & 3.5 \\
\hline - Water Supply & \\
\hline Pipe borne water & 14.3 \\
Underground well water & 85.7 \\
Surface stream & - \\
\hline - Waste Disposal Facilities & 21.3 \\
\hline Free Range- Road side & 65.2 \\
Controlled tipping & 11.7 \\
\hline Incarcerating/Burning & \\
\hline Source Fidd survey, & \\
\hline
\end{tabular}

Source: Field survey, 2006

Access roads are another important facility in the area that needs serious attention. From the survey, $68.3 \%$ of the respondents indicate that their dwellings are accessible by road out of which $32.2 \%$ are not tarred while $29.6 \%$ gain access to their dwellings only by footpaths.

Other facilities investigated in this category include security, school and health facilities. The area does not have security post as indicated by $99.6 \%$ of the respondents. The closest police station is 'A' Division, beside Cultural Centre at Alagbaka, which is about 3 to 4 kilometres farther away. The effect of this on the area is the attendant experiences of burglary as indicated by $66.1 \%$ of the respondents, either occasionally (63\%) or regularly (3.1\%). Educational facilities available are only 
limited to preliminary level of nursery and primary education of which majority are privately owned by some individuals at exorbitant cost for the poor people to benefit. The few public schools available cannot support the teeming population of the school age children in the area.

The state of health facilities is far below satisfaction. A large number of the respondents are having the facilities either farther away from their dwellings or completely absent within their neighbourhoods. About $73.9 \%$ indicate non-availability of health facilities while only $26.1 \%$ is accessible to health facilities, either ordinary chemist store or mini health centre within their neighbourhood. (See table 4).

Beside these, household facilities were investigated to determine the level of individual satisfaction and comfort derived from their dwellings. From the survey, $60 \%$ indicates inadequacy of household facilities, taking into consideration the density ratio of the users. About $37 \%$ indicates fairly adequate while only $3 \%$ indicates satisfactorily with the level of household facilities provided. Drainage facility was equally examined. The survey reveals the absence of this facility in some parts of the area while they are being misused where they are provided through incessant dumping of refuse and human defecation without regular removal.

The inadequacy or lack of basic facilities in the area of study has its numerous attendant problems on the general environment, socio-economic lifestyle, and the health of residents. The larger parts of the housing environment has been rendered unattractive for lack of essential services like water, access roads, regular supply of light, school, and health facilities. The findings reconfirm the works of Olanrewaju and Akinbamijo (2002) in which they reported that environment has great and obvious effects on the health of the inhabitants. For example, regular deposit of refuse on Ala waterways, building of structure on the waterways and non-provision of drainage are causative factors attributed to annual flooding of Ala River (Olanrewaju and Fadairo, 2003). As a result, about $42.6 \%$ attested to outbreak of communicable diseases and other environmental related problems like malaria fever (29.6\%), typhoid fever (23.5\%), and flooding (20.4\%). About 11.3\% complain of diarrhea while 9.1\% indicate cholera. Suggested causative factors include poor water supply (14.8\%), dirty environment (14.8\%), overcrowding (12.2\%), and poor drainage (0.9\%). (See table 5). 
Table 4 Distribution of General Facilities

\begin{tabular}{lc}
\hline - Electricity Supply (Source) & Percentage \\
\hline NEPA & 90.9 \\
Self generating plant & 1.7 \\
None (Hurricane Lamp) & 7.4 \\
\hline - Electricity supply (Availability) & \\
\hline Constant/Regular & 3.0 \\
Erratic/Irregular & 89.6 \\
Not available & 7.4 \\
\hline - Road Accessibility & \\
\hline Yes (Available) & 68.3 \\
No (Not Available) & 31.7 \\
\hline - Road condition & 38.3 \\
\hline Tarred & 32.2 \\
Un-tarred & 29.6 \\
Foot-path & \\
\hline - Security Post & 0.4 \\
\hline Yes (Available) & 99.6 \\
No (Not available) & 3.1 \\
\hline - Burglary witnessed & 63.0 \\
\hline Often & 33.9 \\
Occasionally & \\
Not at all & 73.9 \\
\hline - Health Facilities & \\
\hline Yes (Available) & \\
No (Not available) & \\
\hline & \\
\hline & \\
\hline
\end{tabular}

Source: Field survey, 2006

General observation made during the course of survey reveals that the nonchallant attitude and lack of positive action of residents constitute major causes of environmental problems in the area. The smoky ceiling utensils, the bits of excreta thrown around the compounds, the rubbish invaded kitchen that are left upswept, and the indiscriminate refuse dumps around the dwelling places as well as drainages that are not removed nor cared for form parts of the unscrupulous characteristic way of life of the residents. These make the environment much unhealthier and generate hazards that threaten the lives of the people in the area. 
Table 5 Environmental Related Problems and Likely Causative Factors

\begin{tabular}{lc}
\hline Variables & Percentage \\
\hline * Possibility of occurrence & \\
Yes & 42.6 \\
No & 57.4 \\
\hline * Environmental Related Problems & \\
\hline Flooding & 2.04 \\
Cholera & 9.1 \\
Typhoid fever & 23.5 \\
Malaria fever & 29.6 \\
Diahorea & 11.3 \\
No Response & 6.1 \\
\hline * Likely Caustic Factors & \\
\hline Poor Drainage System & 0.9 \\
Dirty Environment & 14.8 \\
Overcrowding & 12.2 \\
Poor water supply & 14.8 \\
No Response & 57.4 \\
\hline
\end{tabular}

Source: Field survey, 2006

\section{Assessment of the Environment and Associated Effects on Residents}

In the assessment of the general environment, not less than $59.1 \%$ of the sampled respondents agreed that their environment is rowdy, probably because of its closeness to the CBD, particularly the Akure Central Market - Erekesan. This was followed by the $28.7 \%$ who affirmed that the environment was dirty, $8.3 \%$ sees theirs to be clean while $2.6 \%$ and $1.3 \%$ assessed their own areas to be busy and water-logged respectively.

\section{RECOMMENDATIONS AND POLICY GUIDELINES}

Based on the major findings in the study, the following recommendations are put toward as policy guidelines toward a sustainable management of the area of study. The first recommendation is the need for upgrading programme through rehabilitation/renovation approach as well as provision of urban basic services. This simply involves rejuvenation of affected parts of the area by retaining some structures that are retainable; rehabilitate old buildings and structures, upgrading the roads that are not tarred and introduction of more roads with a view to open up the blighted areas. It also involves improving the existing infrastructures as well as providing new ones. These are improving the structural quality and aesthetic of the areas. 
Secondly, the generation of employment opportunities, otherwise known, as economic revitalization is highly needed in the area. This will help to improve the level of capital base and potential for capital formation among the residents that will enhance their level of provision for basic household facilities and proper maintenance of buildings. This approach offers future proceed that can sustain any improvement effort that may be put in place to revive the area. Similar to this is the use of effective public enlightenment strategies to affect public awareness and community participation in area of personal hygiene and need for improving sanitary condition in the area. According to Osoko (2000) and Owoeye (2003), an enforcement of environmental sanitation laws on citizens has a little prospect of success without an enlightened public. The starting point therefore is to educate the people on the dangers of poor sanitation on their health and the need for an improved healthy environment.

Beside all these, sanitary services in the areas need urgent attention, particularly water supply and waste disposal facilities. However, mini-water-works or boreholes and public toilets in strategic places in the area are recommended under Urban Basic Service Programme. Also, the efforts of the Waste Management Authority should be well supported through adequate funding so that facilities for effective services to more areas can be enhanced. In the light of this, Local Government Authority should be called to their primary responsibility to ensure regular collection of refuse in these areas. Meanwhile, the reintroduction of old sanitary inspectors, called 'Wolewole' would be needed to reawaken the unconcerned attitude of the residents towards sanitary laws and regulations. Inspections should be made without prior notice so that the people can always prepare to keep their surroundings clean at all times. Efforts should be made as well to ensure punitive measure on any culprit who violates such orders. It is equally recommended that the proposed channelization project of Ala waterway should be implemented with urgent attention so as to check the menace of seasonal problem of flooding that causes panic to the residents around the area. The state government is therefore called upon to support the initial efforts of the Ecological Department of the Federal Ministry of Environment in redeeming the sanitary image of the area. The assistance of international bodies like UNICEF and the United Nations Centre for Human Settlements (HABITAT) is requested for an effective and enduring renewal programme to be carried out in the area.

\section{ACKNOWLEDGEMENT}

I sincerely appreciate the effort of my field assistant Mr.Owoeye, J.O in the area of data collection for this work. 


\section{REFERENCES}

Abiodun J.O (1995). The Provision of Housing and Urban Environment Problems in Nigeria; in Urban and Regional Planning Problems in Nigeria (pp. 174-191). Nigeria: University of Ife Press Ltd.

Adedeji, Y.M.D (2004). Sustainable Housing for Low-Income Industrial Workers in Ikeja - Ilupeju Estate: Materials Initiative Options. Paper presented at the School of Environmental Technology, Federal University of Technology, Akure.

Aribigbola, A. (2001). Housing and Nigerian Development: Assessment of Policy Measure and Direction. African Journal of Environmental Studies, 2(2), 117-122. Basorun, J.O (2003). Basic Elements of Urban and Regional Planning. Akure, Ondo State, Nigeria: Shalom Publishers.

Bello, A.A. (2002). An Appraisal of Socio-Economic Effects of Slum Environment on Urban Dwellers: A case study of Osogbo in Osun State. Unpublished B. Sc. Thesis, Obafemi Awolowo University, Ile-Ife, Nigeria.

Fadamiro, J.A (2001). An Appraisal of Architectural Principles in the Provision and Maintenance of Affordable Rural Housing. Paper presented at the National Conference on Rural Environment and Sustainable Development, University of Ado-Ekiti, Nigeria.

Federal Ministry of Housing and Environment, Lagos (1982). Rural Housing in the Southern States of Nigeria, Final Report. Jointly Prepared by Ibadan: Physical Planning and Development Division, Nigerian Institute of Social and Economic Research (NISER) and Faculty of Environmental Design and Management, University of Ife, Ile-Ife, Nigeria.

George, C.K. (1999). Basic Principles and Methods of Urban and Regional Planning. Lagos, Nigeria: Libra - Gen Limited.

Modupe, O. (1986, April). Housing Provision in a Depressed Economy. Paper presented at the then Ondo State Polytechnic Owo, Nigeria.

Olanrewaju, D.O (2004, October). Town Planning: A Veritable Means for Poverty Reduction. $38^{\text {th }}$ Inaugural Lecture, Federal University of Technology, Akure.

Olanrewaju, D.O and Akinbamijo, O.B(2002). Environmental Health and Target Audience: A Programmatic Panacea for Poverty Alleviation in Nigerian Cities. African Journal of Environmental Studies, 3(2), 82-89.

Olanrewaju, D.O and Fadamiro, G (2003). Flooding as an Induced Environmental Problem. A case Study of Ala River in Akure, Nigeria. Journal of the Nigerian Institute of Town Planners, 6(1), 85-95. 
Omole, F.K. (2001). Basic Issues in Housing Development. Ondo, Nigeria: Femo Bless Publication .

Onibokun, A.G and Kumuyi, A.S (1996). Urban Poverty in Nigeria: Towards Sustainable Strategies for its Alleviation. Nigeria: Centre for African Settlements Studies and Development (CAESDO).

Onibokun, A.G (1985). Housing in Nigeria: A Book of Reading. Nigeria: Nigeria Institute of Social and Economic Research (NISER).

Onoekerhoraye, A. G. (1995). Urbanization and Environment in Nigeria: Implication for Sustainable Development. Nigeria: The Benin Social Science Series for Africa, University of Benin.

Osoko, O.S (2000). Environmental Sanitation and the Health of the People of Ogun State: A Case Study of Abeokuta. Unpublished MURP Dissertation, University of Ibadan, Nigeria.

Owoeye, J. O. (2003). An Assessment of Public Health and Environmental Sanitation in Akure, Ondo State. Paper presented at the Department of Urban and Regional Planning, Federal University of Technology, Akure, Nigeria.

United Nations Habitat Report (1989). Report of the Commission on Human Settlement on the Work of Its Twelfth Session (Forty -Fourth Session Supplement No 8 (A/44/8)). New York: United Nations General Assembly.

Wahab, B. (2001). Grassroots Participation in Sustainable Urban Development of Slum and Squatter Settlement. Paper presented at the $32^{\text {nd }}$ Annual Conference of the Nigerian Institute of Town Planners, Uyo, Akwa Ibom State. 